\title{
Defaecation and urination behaviour in beef cattle grazing semi-natural grassland
}

\author{
Robert J. Orr*, Bruce A. Griffith, Robert A. Champion, James E. Cook \\ Rothamsted Research, North Wyke, Okehampton, Devon EX20 2SB, UK
}

\section{A R T I C L E I N F O}

\section{Article history:}

Accepted 14 March 2012

Available online 9 April 2012

\section{Keywords:}

Beef cattle

Grazing

Defaecation

Urination

Grassland

\begin{abstract}
A B S T R A C T
There is increasing global interest in the extent to which multi-species grasslands containing increased plant diversity compared with improved grasslands can also deliver higher resource protection. The objective of this experiment was to examine nutrient returns via faeces and urine by free-ranging cattle grazing semi-natural grassland which contribute to leaching losses to ground water along with volatilisation and denitrification losses to the atmosphere. Reduction of grazing intensity has frequently been recommended to meet biodiversity and production goals in sustainable grazing systems. In this experiment beef cattle were continuously stocked on semi-natural (Lolium perenne-Cynosurus cristatus) grassland at grazing intensities which were designed to either utilise herbage growth for optimum livestock production (Moderate), or to increase biodiversity by not fully utilising herbage growth (Lenient) in three replicate blocks. Observations were made in May and September of the number and timing of individual defaecation and urination events between dawn and dusk. In addition, the quantities of fresh material excreted in individual defaecation or urination events were collected and measured. For cattle grazing the Moderate and Lenient treatments, respectively, the daily number of defaecation events was 10.0 vs. 9.3 $(F$ prob. $=0.448)$ in May; 10.0 vs. $9.8(F$ prob. $=0.821)$ in September. The estimated daily total of fresh faeces excreted animal ${ }^{-1}$ was $10.8 \mathrm{vs}$. $9.5 \mathrm{~kg}$ ( $F$ prob. $=0.503$ ) in May; 15.3 vs. $17.4 \mathrm{~kg}(F$ prob. $=0.480)$ in September. The daily number of urinations was $13.4 \mathrm{vs.} 13.5$ $(F$ prob. $=0.941)$ in May; 9.4 vs. $12.7(F$ prob. $=0.077)$ in September. The estimated daily total amount of urine produced animal $^{-1}$ was 9.9 vs. $10.4 \mathrm{~kg}(F$ prob. $=0.808)$ in May; 7.2 vs. $11.9 \mathrm{~kg}$ in September $(F$ prob. $=<0.001)$. Subsamples of faeces and urine were analysed for $\mathrm{N}$ and $\mathrm{P}$ concentrations. The total daily outputs of $\mathrm{N}$ (faeces + urine) animal ${ }^{-1}$ were 77 vs. $75 \mathrm{~g} \mathrm{~N}$ day $^{-1}(F$ prob. $=0.903)$ in May; 96 vs. $122 \mathrm{~g} \mathrm{~N} \mathrm{day}^{-1}(F$ prob. $=0.369)$ and urine $\mathrm{N}$ as a proportion of the total $\mathrm{N}$ excreted was $0.51 \mathrm{vs.} 0.58$ in May ( $F$ prob. $=0.215) ; 0.53$ vs. 0.59 in September $(F$ prob. $=0.464$ ). Most of the P excreted (proportionately 0.99 ) was excreted in the faeces for both grazing intensities in May and September. The daily numbers of excretion events animal ${ }^{-1}$ were similar to other published values but a lower proportion of the total daily $\mathrm{N}$ output was excreted as urine compared with published values for cattle grazing fertilised, improved intensive swards. The potential impact of this on losses to soil water and the atmosphere should be examined.
\end{abstract}

(C) 2012 Elsevier B.V. All rights reserved.

\footnotetext{
* Corresponding author. Tel.: +44 1837 883546; fax: +44 183782139.

E-mail address: robert.orr@rothamsted.ac.uk(R.J. Orr).
}

\section{Introduction}

The maintenance and restoration of species-rich, semi-natural grassland is an integral part of a global move towards sustainable, multifunctional grassland 
management. The competitive balance between plant species (Scimone et al., 2007) may be modified using grazing management prescriptions to modify the species composition of semi-natural pastures by exploiting the dietary choices of the animals (Dumont et al., 2007). Grazing affects biodiversity (e.g. Rook et al., 2004) but if wider issues of sustainability are to be addressed, there is also a need to identify sward composition goals for optimum nutrient use efficiency (Orr et al., 2012) and this requires an understanding of the temporal and spatial patterns of excretion by grazing animals in semi-natural grasslands (Taylor et al., 1987; Morton and Baird, 1990; Semmartin and Oesterheld, 2001; Hutchings et al., 2007).

The return of excreta to the soil in the form of faeces and urine (Parsons et al., 1991) and the consequent loss of some of the $\mathrm{N}$ to soil water in leaching (Hack-ten Broeke and Van der Putten, 1997) and to the atmosphere as a result of denitrification (Yamulki et al., 1998) and ammonia volatilisation (Petersen et al., 1998) are important components of the $\mathrm{N}$ cycle in grazed pastures. The proportion of the daily total $\mathrm{N}$ that is excreted by grazing animals in urine has been shown to increase as the $\mathrm{N}$ concentration in herbage increases. For example, Orr et al. (1995) showed how for ewes grazing unfertilised grass, urine $\mathrm{N}$ comprised $76 \%$ of their total $\mathrm{N}$ excreted compared with $84 \%$ for ewes grazing $\mathrm{N}$-fertilised grass swards in two grazing seasons. In contrast, for herbivores $\mathrm{P}$ is excreted mainly in faeces (Karn, 2001) and originates largely from unabsorbed salivary P. Intensive grazing can lead to the degradation of the soil in grassland environments (Bilotta et al., 2007) through impacts on hydrology and water quality (sediments and colloids with associated sorbed P) in surface waters.

For free-ranging herbivores the daily separate collection and measurement of faeces and urine is problematical and various methods to do this have been published in the literature (Jeffery, 2004; Kartchner and Rittenhouse, 1979). Urethral catheters may be used (e.g. Lesperance and Bohman, 1961; Stillwell et al., 1983) but this approach may affect behaviour and potentially compromise welfare. Betteridge and Andrewes (1986) developed a non-surgical device which collected a pre-determined proportion of the urine voided and used this device (Betteridge et al., 1986) to look at intake and excretion of $\mathrm{N}, \mathrm{P}$ and $\mathrm{K}$ in trials with grazing steers.

The aim of this study was to examine defaecation and urination behaviour in beef cattle grazing semi-natural grassland and in particular to observe temporal patterns of excretion. Two levels of grazing intensity, within the range which is likely to be used for these grassland types, were used. The number of defaecation and urination events was determined by observation and the total amount of fresh excreta produced in single elimination events was collected in containers, to be weighed and subsampled. Patterns of defaecation and urination were examined and $\mathrm{N}$ and $\mathrm{P}$ excretions were related to $\mathrm{N}$ and $\mathrm{P}$ ingestion to determine apparent efficiency of nutrient capture. It was predicted from indoor feeding studies in the literature that as the $\mathrm{N}$ concentration of ingested herbage was likely to be low, this was likely to impact on the proportion of $\mathrm{N}$ excreted as urine compared with $\mathrm{N}$ fertilised grass.

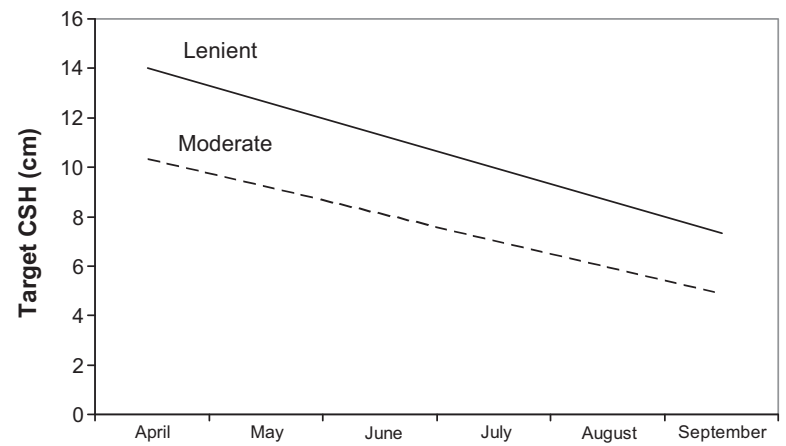

Fig. 1. Seasonal pattern of target compressed sward height (CSH), measured using a rising platemeter, for semi-natural grassland grazed at Moderate or Lenient intensity.

\section{Materials and methods}

\subsection{Swards and treatments}

The experiment was conducted in 2006 at a site in SW England $\left(50^{\circ} 46^{\prime} \mathrm{N} 3^{\circ} 54^{\prime} \mathrm{W}\right)$ on swards which are classified as MG6 (Lolium perenne-Cynosurus cristatus) grassland communities under the UK National Vegetation Classification (Rodwell, 1992). Two grazing intensities, which were designed to either utilise herbage growth for optimum livestock production (Moderate) or to increase biodiversity by not fully utilising herbage growth (Lenient), were imposed on the semi-natural grassland in three replicate blocks. In the previous four years these treatment areas were grazed at these same intensities (Isselstein et al., 2007; Orr et al., 2012).

\subsection{Animals}

Six different core groups of four Charolais $\times$ Holstein Friesian steers, which had been born in March 2005, were continuously stocked on three Moderate areas (each 1.5 ha) and three Lenient areas (each 3 ha). Additional similar spare animals were available as plot grazers, when required, to maintain the grazing treatments and these grazed similar swards to the treatment swards.

\subsection{Measurements}

\subsubsection{Compressed sward height}

CSH was measured using a rising platemeter (Ashgrove Pastoral Products, Palmerston North, New Zealand) with 100 contacts per paddock. The Moderate or Lenient target sward heights (Fig. 1) were maintained using continuous variable stocking with livestock numbers adjusted as required to maintain the target CSHs. These target heights were used previously at this site by Isselstein et al. (2007) and Orr et al. (2012).

\subsubsection{Animal liveweight}

The cattle were weighed on five occasions (21 April, 2 June, 18 June, 24 August and 22 September) during the grazing season and daily liveweight gain was calculated. 


\subsubsection{Elimination events}

Observations were made of the number and timing of individual defaecation and urination events by the four core steers in each group between dawn and dusk on two occasions. The animals were habituated to the presence of observers and could be approached closely ( $<1 \mathrm{~m})$ without visible influence on their behaviour (Lamoot et al., 2004). Observations were conducted on each block in succession on 9, 15 and 30 May; then 1, 15 and 21 September, respectively, for the three blocks. On each of these dates observations were made on a Moderate group and a Lenient group simultaneously.

\subsubsection{Ingestion}

Herbage intake was measured for the core steers in each block in succession on two occasions using an n-alkane dosing technique (Dove and Mayes, 1991). Paper pellets containing $\mathrm{C}_{32}$ (dotriacontane) were dosed once daily at approximately $09.00 \mathrm{~h}$ British Summer Time (BST) for 11 days where for the three blocks, respectively, day 1 was 2, 8 and 23 May; then 27 August, 10 September and 17 September. On each of these dates measurements were made on a Moderate group and a Lenient group simultaneously. For dosing, the cattle were briefly moved from the paddocks to handling pens adjacent to a loafing area near to where their drinking water trough was located. Drinking water was available at all times when the cattle were on the paddocks. Samples of fresh naturally voided faeces were collected each day from the pasture on days 9-11 and bulked separately for each steer. Herbage samples were snipped with scissors on day 10 from the grazed horizon of the sward and these were intended to be representative of the material selected by the cattle. Mean daily herbage DM intake was calculated from the dosed rate of $C_{32}\left(745 \mathrm{mg} \mathrm{day}^{-1}\right)$ and the concentrations of $C_{32}$ and $C_{33}$ (tritriacontane) in herbage and faeces. $\mathrm{N}$ and $\mathrm{P}$ concentrations were determined on the dried herbage snip samples and $\mathrm{N}$ and $\mathrm{P}$ intakes were calculated. Herbage samples were also analysed for water soluble carbohydrate (WSC) (Thomas, 1977) and digestibility (DOMD in vitro) (Jones and Haywood, 1975).

\subsubsection{Excretion}

The total amount of faeces voided and urine eliminated in single excretion events was collected from each of the core animals (one sample in the morning and another in the afternoon) in each group. They were trained to become accustomed to being approached and became sufficiently tractable that the excreta could be collected in containers. In some cases, this was achieved when the animals were on the plots or alternatively they were moved for short periods into a $3 \mathrm{~m} \times 3 \mathrm{~m}$ pen adjacent to their loafing area. Samples were collected over several days (until a morning and afternoon sample was collected from each steer) beginning 10, 24 May and 12 June; then 18, 20 and 25 September, respectively, for the three blocks. The samples of faeces and urine from individual events were weighed, subsampled (approximately $50 \mathrm{ml}$ of urine or $350 \mathrm{~g}$ of faeces for each event), rapidly chilled and then frozen. They were subsequently analysed for $\mathrm{N}$ and $\mathrm{P}$ concentrations, with $\mathrm{N}$ concentration being determined on fresh faeces by

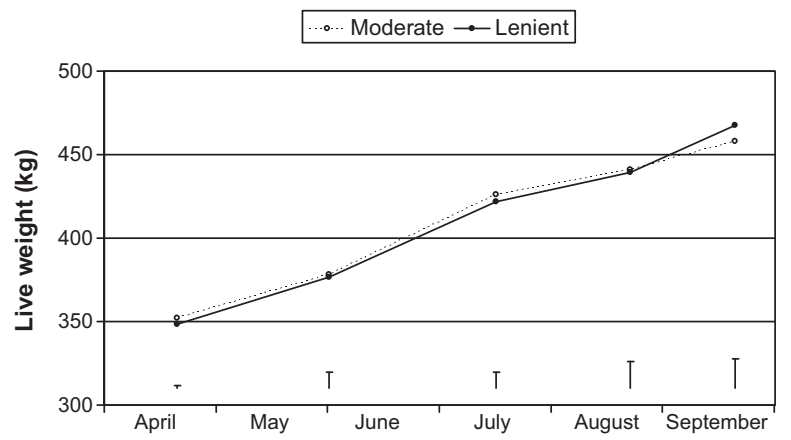

Fig. 2. Cattle liveweight on semi-natural grassland grazed at Moderate or Lenient intensity. Error bars indicate s.e.d.

the Kjeldahl method, whereas P was determined on ovendried faeces. $\mathrm{N}$ and $\mathrm{P}$ analyses were also determined on fresh urine.

The total daily outputs of $\mathrm{N}$ and $\mathrm{P}$ in faeces and urine were estimated from the number of excretion events observed and the amounts and concentration of nutrients in the excreta.

\subsection{Statistical analyses}

Mean values for the 'group' of cattle were used as the unit of replication $(n=6)$ in all statistical analyses as individual animals in a group cannot necessarily be regarded as statistically independent (Rook and Penning, 1991). Data were analysed by one-way ANOVA using GenStat (www.vsni.co.uk) following tests for normality which established that they were all normally distributed. As measurements were made on a Moderate group and a Lenient group simultaneously in each block in succession, this reduced any measurement-day effect. Measurements were made in May and September and the analyses tested the effects of season and looked for interactions between season and grazing intensity.

The data on the timing of individual defaecation and urination events were examined using the PTDESCRIBE procedure in GenStat which gives a summary and second order statistics for a point process or series of events (Cox and Lewis, 1966). These are characterised both by the times at which events occur and the intervals between them. The Poisson process was used which is the most basic point process with Poisson counts in any interval and independent exponentially distributed intervals between events.

\section{Results}

\subsection{Liveweight gain and stocking rate}

The cattle grazed the paddocks from 28 April until 29 September. For the Moderate and Lenient treatments, respectively, they weighed $352 \mathrm{vs} .348 \mathrm{~kg}(F$ prob. $=0.122)$ at turnout (Fig. 2) and up to the end of the grazing season individual daily liveweight gains were similar (0.69 vs. $0.77 \pm$ s.e.d. $0.109 ; \mathrm{kg}$ animal $^{-1}, F$ prob. $=0.512$ ).

Over the 22-week grazing season, the Moderate and Lenient paddocks supported 360 and 290 ( \pm s.e.d. 84.0; F 


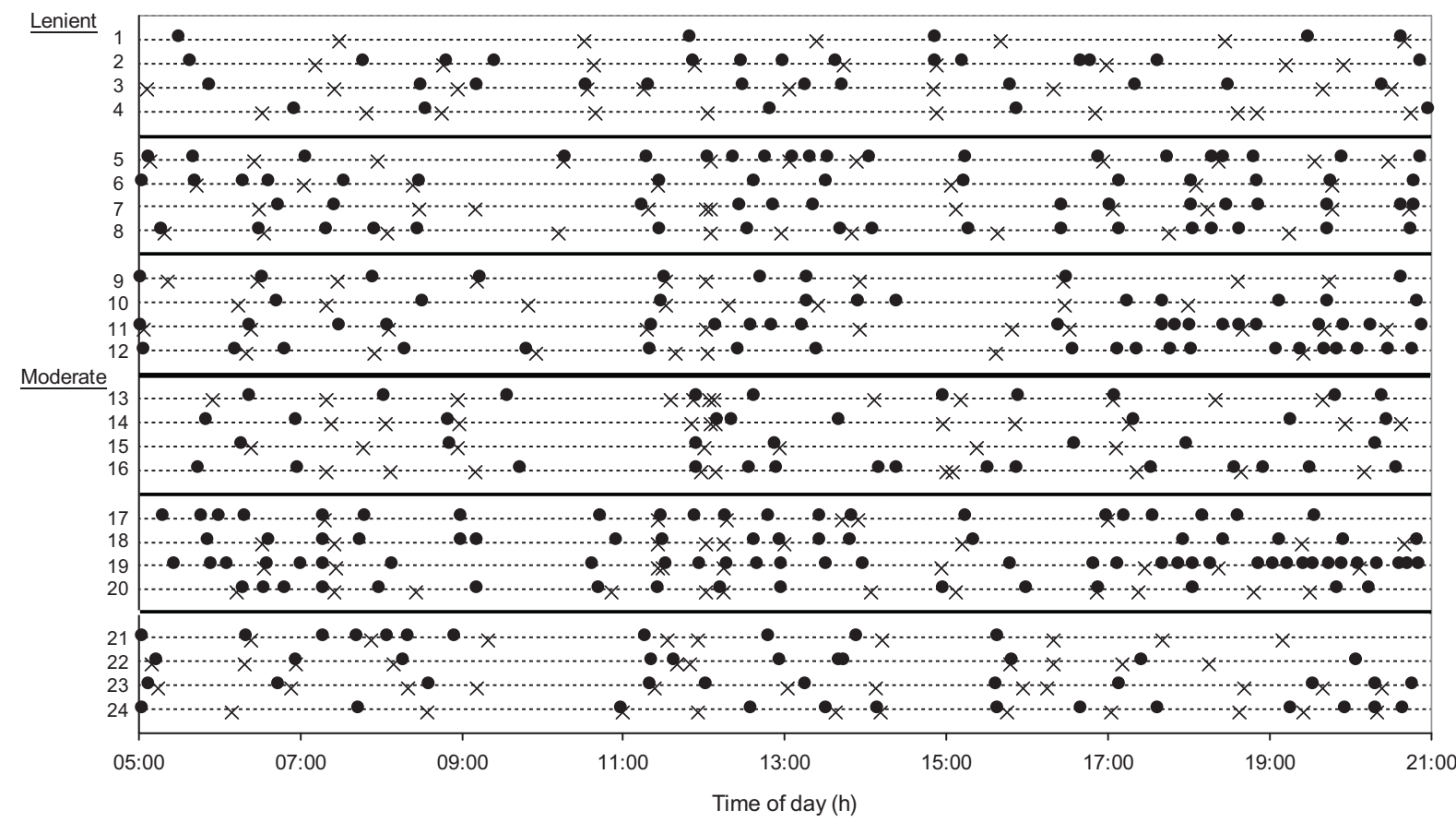

Fig. 3. Faeces $(x)$ and urine $(\bullet)$ elimination events for individual cattle grazing in groups at Lenient $(1-4,5-8$ and $9-12)$ or Moderate (13-16, 17-20 and 21-24) intensity measured in May.

prob. $=0.491$ ) cattle grazing days ha ${ }^{-1}$, respectively, which was equivalent to a mean daily stocking rate of 2.3 and 1.9 ( \pm s.e.d. $0.54 ; F$ prob. $=0.491$ ) animals ha ${ }^{-1}$. Total liveweight gains over the season were 235 and $229 \mathrm{~kg} \mathrm{ha}^{-1}$ ( \pm s.e.d. $55.0 ; F$ prob. $=0.921$ ).

\subsection{Defaecation and urination events}

Observations of elimination events between dawn and dusk are shown from 05.00 to 21.00 h BST in May in Fig. 3 and from 06.00 to $20.00 \mathrm{~h}$ BST in September in Fig. 4. One steer (\#19) had an uncharacteristically high number of urinations (34 in May; 25 in September) and all data have been excluded for this animal. There was some evidence of temporal synchrony in defaecation and urination, with one type of elimination event closely followed by the other, but there was no consistency in whichever occurred first. Also, there was some synchrony (Figs. 3 and 4) in excretion activity between animals in the same group for the six groups (i.e. Lenient: Groups 1-4, 5-8, 9-12 and Moderate: Groups 13-16, 17-20, 21-24).
Whilst the steers grazing at Lenient intensity in September tended to have more urinations $(F$ prob. $=0.077)$ and a shorter interval between urinations ( $F$ prob. $=0.057)$ than those grazing at Moderate intensity (Table 1), there was no significant effect of treatment on the number of defaecations or urinations recorded - or the interval between individual defaecation or urination events. Overall, the steers had fewer urinations in September compared with May ( 11.0 vs. $13.4 ; F$ prob. $=0.017$ ) but there were no significant interactions between season and grazing intensity.

\subsection{Intake and excretion}

\subsubsection{Herbage analysis and faeces or urine excreted at individual elimination events}

The sward height values achieved in May (Table 2) were 7.1 and $11.1 \mathrm{~cm}$ compared with the target heights (Fig. 1) for that stage of the season which were 9.1 and $12.5 \mathrm{~cm}$. Whilst the heights achieved were lower than the target, they were significantly

Table 1

Number of defaecation and urination events and interval between events, recorded between dawn and dusk in May and September.

\begin{tabular}{|c|c|c|c|c|c|c|c|c|c|}
\hline & \multicolumn{2}{|c|}{ May $(05.00-21.00 \mathrm{~h})$} & \multirow[t]{3}{*}{ s.e.d. } & \multirow[t]{3}{*}{$F$ prob. } & \multirow{2}{*}{\multicolumn{2}{|c|}{$\begin{array}{l}\text { September } \\
(06.00-20.00 \mathrm{~h}) \\
\text { Grazing intensity }\end{array}$}} & \multirow[t]{3}{*}{ s.e.d. } & \multirow[t]{3}{*}{$F$ prob. } & \multirow{3}{*}{$\begin{array}{l}\text { Effect of season } \\
\text { F prob. }\end{array}$} \\
\hline & \multicolumn{2}{|c|}{ Grazing intensity } & & & & & & & \\
\hline & Moderate & Lenient & & & Moderate & Lenient & & & \\
\hline No. of defaecations & 10.0 & 9.3 & 0.71 & 0.448 & 10.0 & 9.8 & 0.75 & 0.821 & 0.721 \\
\hline No. of urinations & 13.4 & 13.5 & 1.69 & 0.941 & 9.4 & 12.7 & 0.98 & 0.077 & 0.017 \\
\hline Mean interval between defaecations (min) & 90.7 & 102.5 & 10.33 & 0.373 & 88.6 & 87.2 & 6.38 & 0.846 & 0.265 \\
\hline Mean interval between urinations (min) & 77.8 & 94.1 & 15.03 & 0.392 & 98.8 & 74.9 & 5.96 & 0.057 & 0.906 \\
\hline
\end{tabular}




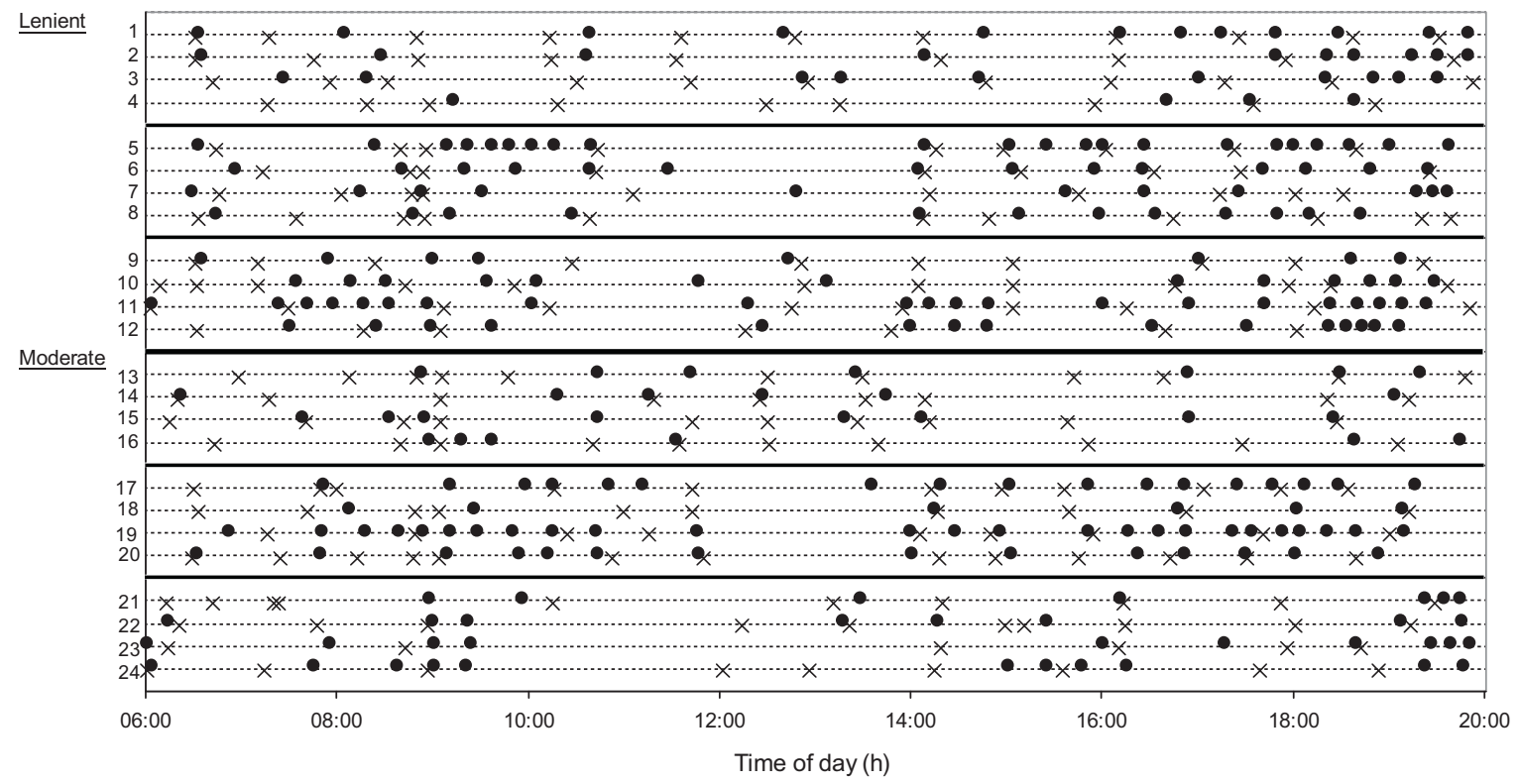

Fig. 4. Faeces $(x)$ and urine $(\bullet)$ elimination events for individual cattle grazing in groups at Lenient $(1-4,5-8,9-12)$ or Moderate (13-16, 17-20, 21-24) intensity measured in September.

different ( $F$ prob. $=0.042$ ). There were no significant differences in May between treatments in herbage digestibility, WSC, $\mathrm{N}$ and $\mathrm{P}$ concentrations and overall values were $630 \mathrm{mgDOM} \mathrm{g}^{-1} \mathrm{DM}, 149 \mathrm{mg} \mathrm{WSC}^{-1} \mathrm{DM}$, $22.7 \mathrm{mg} \mathrm{N} \mathrm{g}^{-1} \mathrm{DM}$ and $2.3 \mathrm{mg} \mathrm{Pg}^{-1} \mathrm{DM}$.

In September the swards were shorter than they had been in May, reflecting the lower target heights (5.0 and $7.3 \mathrm{~cm}$ ). The actual sward height values achieved were 6.3 and $8.3 \mathrm{~cm}$ i.e. slightly higher than the target heights but, as in May, there was still a significant ( $F$ prob. $=0.013$ ) separation between the grazing intensity treatments. As in May, there were no significant differences between treatments in the digestibility, WSC, N and $\mathrm{P}$ concentrations of herbage and overall values were $571 \mathrm{mg} \mathrm{DOM} \mathrm{g}^{-1} \mathrm{DM}, 119 \mathrm{mg} \mathrm{WSC}^{-1} \mathrm{DM}, 23.3 \mathrm{mg} \mathrm{N} \mathrm{g}^{-1}$ $\mathrm{DM}$ and $2.5 \mathrm{mg} \mathrm{Pg}^{-1} \mathrm{DM}$. There were significant effects of season (Table 2) on herbage analyses and in September there were reduced values for DOMD and WSC; similar

Table 2

Herbage analysis and faeces or urine excreted at individual elimination events measured in May and September.

\begin{tabular}{|c|c|c|c|c|c|c|c|c|c|}
\hline & \multicolumn{2}{|l|}{ May } & \multirow[t]{3}{*}{ s.e.d. } & \multirow[t]{3}{*}{$F$ prob } & \multirow{2}{*}{\multicolumn{2}{|c|}{$\frac{\text { September }}{\text { Grazing intensity }}$}} & \multirow[t]{3}{*}{ s.e.d. } & \multirow[t]{3}{*}{$F$ prob. } & \multirow{3}{*}{$\begin{array}{l}\text { Effect of season } \\
F \text { prob. }\end{array}$} \\
\hline & \multicolumn{2}{|c|}{ Grazing intensity } & & & & & & & \\
\hline & Moderate & Lenient & & & Moderate & Lenient & & & \\
\hline \multicolumn{10}{|l|}{ Herbage analysis } \\
\hline Compressed sward height $(\mathrm{cm})$ & 7.1 & 11.1 & 0.82 & 0.042 & 6.3 & 8.3 & 0.22 & 0.013 & 0.013 \\
\hline $\mathrm{DOMD}\left(\mathrm{mg} \mathrm{DOM} \mathrm{g}^{-1} \mathrm{DM}\right)$ & 630 & 629 & 7.5 & 0.947 & 567 & 574 & 10.3 & 0.558 & 0.006 \\
\hline WSC $\left(\mathrm{mg} \mathrm{g}^{-1} \mathrm{DM}\right)$ & 147.3 & 150.5 & 5.43 & 0.609 & 122.1 & 115.3 & 4.84 & 0.296 & 0.011 \\
\hline $\mathrm{N}\left(\mathrm{mgg}^{-1} \mathrm{DM}\right)$ & 22.5 & 22.9 & 0.34 & 0.341 & 22.4 & 24.2 & 1.33 & 0.308 & 0.464 \\
\hline $\mathrm{P}\left(\mathrm{mgg}^{-1} \mathrm{DM}\right)$ & 2.3 & 2.3 & 0.28 & 0.792 & 2.4 & 2.7 & 0.22 & 0.248 & 0.002 \\
\hline \multicolumn{10}{|l|}{ Faeces } \\
\hline Fresh faeces ( g event $^{-1}$ ) & 1069 & 1029 & 192.9 & 0.855 & 1545 & 1763 & 223.1 & 0.432 & $<0.001$ \\
\hline Faeces DM\% & 12.2 & 10.4 & 0.73 & 0.126 & 12.0 & 11.5 & 0.43 & 0.360 & 0.486 \\
\hline Dry faeces ( g event $\left.^{-1}\right)$ & 128 & 101 & 16.0 & 0.235 & 186 & 200 & 25.5 & 0.633 & $<0.001$ \\
\hline $\mathrm{N}$ concentration in fresh faeces $\left(\mathrm{mg} \mathrm{g}^{-1}\right)$ & 3.5 & 3.5 & 0.16 & 0.890 & 2.8 & 2.9 & 0.04 & 0.672 & 0.119 \\
\hline $\mathrm{N}$ excreted in faeces $\left(\mathrm{g} \mathrm{event}^{-1}\right)$ & 3.7 & 3.3 & 0.68 & 0.670 & 4.4 & 5.0 & 0.61 & 0.379 & $<0.001$ \\
\hline P concentration in faecal DM $\left(\mathrm{mg} \mathrm{g}^{-1}\right)$ & 5.0 & 5.9 & 0.57 & 0.227 & 3.8 & 4.7 & 0.11 & 0.012 & 0.093 \\
\hline P excreted in faeces $\left(\right.$ g event $^{-1}$ ) & 0.6 & 0.6 & 0.09 & 0.614 & 0.7 & 1.0 & 0.10 & 0.129 & 0.017 \\
\hline \multicolumn{10}{|l|}{ Urine } \\
\hline Fresh urine $\left(\right.$ g event $\left.^{-1}\right)$ & 745 & 754 & 113.9 & 0.942 & 740 & 941 & 54.1 & 0.066 & 0.320 \\
\hline $\mathrm{N}$ concentration in fresh urine $\left(\mathrm{mg} \mathrm{g}^{-1}\right)$ & 4.5 & 4.4 & 2.15 & 0.957 & 8.4 & 6.4 & 3.25 & 0.608 & 0.020 \\
\hline $\mathrm{N}$ excreted in urine $\left(\right.$ g event $\left.^{-1}\right)$ & 3.1 & 3.3 & 1.20 & 0.916 & 5.7 & 6.0 & 2.45 & 0.926 & 0.009 \\
\hline$P$ concentration in fresh urine $\left(\mathrm{mg} \mathrm{g}^{-1}\right)$ & 0.0044 & 0.0032 & 0.0025 & 0.659 & 0.0054 & 0.0027 & 0.00252 & 0.396 & 0.668 \\
\hline P excreted in urine $\left(\right.$ g event $\left.^{-1}\right)$ & 0.0030 & 0.0024 & 0.00141 & 0.689 & 0.0037 & 0.0025 & 0.00175 & 0.575 & 0.322 \\
\hline
\end{tabular}

DOMD: digestible organic matter in DM; WSC: water soluble carbohydrate. 
values for $\mathrm{N}$ and increased values for $\mathrm{P}$ concentrations in herbage compared with May, but there were no significant interactions between season and grazing intensity.

In May there was no significant effect of grazing treatment on the amounts and nutrient concentrations in faeces and overall mean values were $1049 \mathrm{~g}$ fresh faeces per defaecation event, at $11.3 \%$ DM, resulting in $115 \mathrm{~g}$ faeces DM per event. $\mathrm{N}$ concentrations in faeces expressed on a dry basis were 29 and $34 \mathrm{mg} \mathrm{N} \mathrm{g}^{-1}$ DM for the Moderate and Lenient treatments, respectively. There were no significant differences in the concentrations of $\mathrm{N}$ and $\mathrm{P}$ in faeces or in the amounts excreted in each defaecation. Similar amounts of urine were produced at each event (mean 750 g event $^{-1}$ ) and the concentrations of $\mathrm{N}$ and $\mathrm{P}$ in urine and the amounts of $\mathrm{N}$ and $\mathrm{P}$ excreted in urine at each event were not significantly different.

There was no significant effect of grazing treatment in September on the amounts excreted in faeces and overall values were $1654 \mathrm{~g}$ fresh faeces per defaecation event, at $11.7 \%$ DM resulting in $193 \mathrm{~g}$ faeces DM per event. $\mathrm{N}$ concentration in faeces expressed on a dry basis was 24 and $25 \mathrm{mg} \mathrm{N} \mathrm{g}^{-1}$ DM for the Moderate and Lenient treatments, respectively. There were no significant differences in the concentrations of $\mathrm{N}$ in faeces or in the amounts of $\mathrm{N}$ and $P$ excreted in each defaecation. However, the $P$ concentration in faecal DM ( $F$ prob. $=0.012$ ) was higher for the steers grazing at Lenient intensity. The steers grazing at Lenient intensity tended $(F$ prob. $=0.066)$ to produce more urine at each event, but the concentrations and amounts of $\mathrm{N}$ and $\mathrm{P}$ excreted in urine were not significantly different.

There were significant effects of season (Table 2) amongst outputs of faeces and urine per elimination event. In September, compared with May, the amounts of fresh faeces, dry faeces, faecal $\mathrm{N}$ and faecal $\mathrm{P}$ per event were all higher. Whilst the $\mathrm{N}$ concentration in fresh urine and the urine $\mathrm{N}$ per event were significantly higher in September than in May, urine P concentration and urine P output per event were not different.

\subsubsection{Daily herbage intake and excretion}

Steers grazing the Moderate and Lenient treatments (Table 3) were similar in weight (378 vs. $377 \mathrm{~kg}$ ) when intake and excretion were measured in May. Daily intakes of herbage DM, N and P in May were not significantly different and mean values were $6.2 \mathrm{~kg} \mathrm{DM} \mathrm{day}^{-1}, 139.7 \mathrm{~g} \mathrm{~N}$ day $^{-1}$ and $14.9 \mathrm{~g} \mathrm{Pday}^{-1}$. The daily output of faeces expressed on a dry basis tended to be higher for cattle grazing the Moderate than the Lenient treatments ( 1.3 vs. $0.9 \mathrm{~kg} \mathrm{DM} \mathrm{day}^{-1} ; F$ prob. $=0.062$ ) but the output of fresh faeces, $\mathrm{N}$ or P excreted in faeces were not affected by treatment. Neither were the output of fresh urine, $\mathrm{N}$ or $\mathrm{P}$ excreted in urine or the total (faeces + urine) $\mathrm{N}$ or P excreted.

In September the cattle weighed 458 vs. $468 \mathrm{~kg}$ for the Moderate and Lenient treatments, respectively. Daily intakes of herbage DM, $\mathrm{N}$ and $\mathrm{P}$ were not significantly different and mean values were $14.0 \mathrm{~kg} \mathrm{DM} \mathrm{day}^{-1}$, $330.0 \mathrm{~g} \mathrm{~N}$ day $^{-1}$ and $36.5 \mathrm{~g} \mathrm{Pday}^{-1}$. The daily output of faeces (fresh or expressed as DM) or faecal $\mathrm{N}$ or $\mathrm{P}$ was not affected by treatment but significantly less urine was excreted by the steers grazing the Moderate than the Lenient treatment (7.2 vs. $11.9 \mathrm{~kg} \mathrm{day}^{-1} ; F$ prob. $\left.=<0.001\right)$.
The output of $\mathrm{N}$ or $\mathrm{P}$ excreted in urine or the total (faeces + urine) $\mathrm{N}$ or $\mathrm{P}$ excreted was not significantly different between treatments.

There were significant effects of season on all the attributes shown in Table 3 except for the estimated daily amounts of fresh urine and urine P produced. Apart from these, all the other intake and excretion data were higher in September than May, when the cattle were older and heavier.

\subsection{Apparent efficiencies of $N$ and $P$ capture}

The apparent efficiencies of $\mathrm{N}$ and $\mathrm{P}$ capture were calculated by subtracting the nutrient outputs from the nutrient inputs (Table 3) to give apparent nutrient capture and then expressing this as a proportion of the input. Values for cattle grazing the Moderate and Lenient treatments, respectively, in May were 39 and $41 \%$ for N; 48 and 55\% for $\mathrm{P}$ and in September were 69 and 58\% for N; 78 and $71 \%$ for P.

\section{Discussion}

\subsection{Animal performance and stocking rate}

Mean daily liveweight gain animal ${ }^{-1}$ in the experiment reported here was $0.73 \mathrm{~kg} \mathrm{day}^{-1}$ for yearling steers grazing semi-natural grassland, which was very similar to values for $\mathrm{N}$ fertilised, reseeded pastures measured on a neighbouring site and reported by Tyson et al. (1992). These authors reported mean gains over 5 consecutive seasons of $0.74 \mathrm{~kg} \mathrm{day}^{-1}$ for Hereford $\times$ Friesian yearling steers weighing $295 \mathrm{~kg}$ at the start of the grazing season grazing perennial ryegrass swards which were fertilised with $400 \mathrm{~kg} \mathrm{~N} \mathrm{ha}^{-1}$. However, over 5 years the annual total of animal grazing days (mean $1250 \mathrm{ha}^{-1}$ ) for fertilised, reseeded pastures was substantially higher than for unfertilised, semi-natural grassland in the experiment reported here (Moderate, 360 vs. Lenient, 290 cattle grazing days $\mathrm{ha}^{-1}$ ) in 2006; or reported by Orr et al. (2012) for 2005 (Moderate, 375 and Lenient, 220 cattle grazing days ha ${ }^{-1}$ ) or by Isselstein et al. (2007) for 2002-2004 at this site (Moderate, 346 vs. Lenient, 235 grazing days ha ${ }^{-1}$ ).

\subsection{Temporal patterns in defaecation and urination}

The observations of defaecation and urination events were conducted between dawn and dusk over $16 \mathrm{~h}$ periods in May and $14 \mathrm{~h}$ periods in September and therefore did not include any excretion that may have occurred outside the photoperiod. Rutter et al. (2006) measured the position (using GPS with sub-metre precision and $60 \mathrm{~Hz}$ position fixing) and behaviour of cattle grazing these paddocks in 2005 at the same intensities and found that generally they stayed in the same location ruminating and resting during the night. Orr et al. (2001) also illustrated how cattle spend the hours of darkness in alternating bouts of rumination and rest. However, this does not preclude the possibility that the cattle in the present study defaecated when laying down or stood briefly to defaecate or urinate and then returned to the same position. 
Table 3

Cattle liveweight, daily herbage intake and excretion measured in May and September.

\begin{tabular}{|c|c|c|c|c|c|c|c|c|c|}
\hline & \multicolumn{2}{|l|}{ May } & \multirow[t]{3}{*}{ s.e.d. } & \multirow[t]{3}{*}{$F$ prob. } & \multirow{2}{*}{\multicolumn{2}{|c|}{$\frac{\text { September }}{\text { Grazing intensity }}$}} & \multirow[t]{3}{*}{ s.e.d. } & \multirow[t]{3}{*}{$F$ prob. } & \multirow{3}{*}{$\begin{array}{l}\text { Effect of season } \\
F \text { prob. }\end{array}$} \\
\hline & \multicolumn{2}{|c|}{ Grazing intensity } & & & & & & & \\
\hline & Moderate & Lenient & & & Moderate & Lenient & & & \\
\hline Cattle liveweight (kg) & 378 & 377 & 9.8 & 0.881 & 458 & 468 & 17.4 & 0.637 & $<0.001$ \\
\hline \multicolumn{10}{|l|}{ Herbage intake } \\
\hline DM intake $\left(\mathrm{kg} \mathrm{day}^{-1}\right)$ & 5.9 & 6.5 & 0.54 & 0.354 & 13.9 & 14.0 & 2.09 & 0.968 & $<0.001$ \\
\hline $\mathrm{N}$ intake $\left(\mathrm{g} \mathrm{day}^{-1}\right)$ & 132 & 148 & 12.3 & 0.317 & 317 & 343 & 38.4 & 0.568 & 0.002 \\
\hline $\mathrm{P}$ intake $\left(\mathrm{g} \mathrm{day}^{-1}\right)$ & 13.4 & 16.4 & 3.62 & 0.490 & 33.1 & 40.0 & 9.82 & 0.556 & 0.004 \\
\hline \multicolumn{10}{|l|}{ Faeces } \\
\hline Fresh faeces (kg day $\left.{ }^{-1}\right)$ & 10.8 & 9.5 & 1.67 & 0.503 & 15.3 & 17.4 & 2.35 & 0.480 & 0.006 \\
\hline Dry faeces $\left(\mathrm{kg} \mathrm{day}^{-1}\right)$ & 1.3 & 0.9 & 0.09 & 0.062 & 1.8 & 2.0 & 0.31 & 0.735 & 0.001 \\
\hline $\mathrm{N}$ excreted in faeces $\left(\mathrm{g} \mathrm{day}^{-1}\right)$ & 36.7 & 30.8 & 5.90 & 0.418 & 43.3 & 49.8 & 6.69 & 0.437 & 0.006 \\
\hline P excreted in faeces $\left(\mathrm{g} \mathrm{day}^{-1}\right)$ & 6.2 & 5.2 & 0.68 & 0.312 & 7.0 & 9.4 & 1.22 & 0.185 & 0.003 \\
\hline \multicolumn{10}{|l|}{ Urine } \\
\hline Fresh urine $\left(\mathrm{kg} \mathrm{day}^{-1}\right)$ & 9.9 & 10.4 & 2.01 & 0.808 & 7.2 & 11.9 & 0.13 & $<0.001$ & 0.453 \\
\hline $\mathrm{N}$ excreted in urine $\left(\mathrm{g}\right.$ day $\left.^{-1}\right)$ & 40.3 & 44.2 & 10.57 & 0.745 & 53.1 & 72.2 & 18.62 & 0.412 & 0.009 \\
\hline P excreted in urine $\left(\mathrm{g} \mathrm{day}^{-1}\right)$ & 0.04 & 0.03 & 0.013 & 0.553 & 0.03 & 0.03 & 0.015 & 0.768 & 0.458 \\
\hline \multicolumn{10}{|l|}{ Total faeces + urine } \\
\hline $\mathrm{N}$ excreted $\left(\mathrm{g} \mathrm{day}^{-1}\right.$ ) & 77.0 & 75.0 & 14.78 & 0.903 & 96.4 & 122.0 & 22.3 & 0.369 & 0.003 \\
\hline P excreted $\left(\mathrm{g} \mathrm{day}^{-1}\right)$ & 6.2 & 5.3 & 0.69 & 0.315 & 7.0 & 9.4 & 1.22 & 0.187 & 0.003 \\
\hline
\end{tabular}

The cattle were invariably lying down at the start of the observation periods at dawn and care was taken not to approach them closely and possibly disturb them, but rather to observe from a distance until they stood voluntarily. Similar care not to cause disturbance was also taken at the approximately $4 \mathrm{~h}$ intervals when new observers took over the recording.

Whitehead (1995) suggested in a review that the frequency of urination in cattle is generally about 8-12 times per day and is influenced considerably by diet, weather conditions (volumes are lower in drier than wet weather), the physiological state of the animal and the concentration of $\mathrm{N}$ in the diet. In the present study for cattle grazing the Moderate and Lenient treatments, respectively, values were 13.4 vs. 13.5 urinations day $^{-1}$ in May; 9.4 vs. 12.7 urinations day ${ }^{-1}$ in September, i.e. at the upper level or slightly above this range. However, the daily number of defaecations (9.3-10.0) was within the range suggested by Whitehead (1995) of 7-15 times per day. Aland et al. (2002) reported in a study with housed dairy cows that there were more defaecations (16.1) than urinations (9.0) per 24-h period in contrast to the results in the present study for free-ranging beef cattle.

In some cases the synchrony in eliminative activity within a group occurred when the four steers had all been lying down and resting or ruminating for a period of approximately $1 \mathrm{~h}$. Then, they progressively stood and either defaecated or urinated before starting to graze, with the other eliminative event often occurring in each case within $10-15 \mathrm{~min}$ of them standing. Unlike horses, for which grazing ceases during urination in the majority of instances (Lamoot et al., 2004), the steers urinated whilst standing, walking or grazing.

\section{3. $N$ and $P$ excretion}

The daily amounts of $\mathrm{N}$ and $\mathrm{P}$ excreted animal ${ }^{-1}$ were not significantly different between the Moderate and
Lenient treatments. Mean values in May were $76 \mathrm{~g} \mathrm{~N}^{-1 a y}{ }^{-1}$ and $6 \mathrm{~g} \mathrm{Pday}^{-1}$ and in September were $109 \mathrm{~g} \mathrm{~N}$ day $^{-1}$ and $8 \mathrm{~g} \mathrm{P}$ day $^{-1}$. However, the Moderate treatment supported proportionately 0.24 more cattle grazing days (360 vs. 290 days) than the Lenient treatment and therefore the excretal $\mathrm{N}$ and $\mathrm{P}$ returns ha ${ }^{-1}$ would also have been higher. It can also be presumed that in $\mathrm{N}$ fertilised, improved pastures which may support 3 to 4 times the stocking rate (e.g. Tyson et al., 1992) of these unfertilised, semi-natural pastures the nutrient returns via excreta are also likely to be substantially higher and the soil moisture content is likely to be reduced as a result of increased evapotranspiration losses (Murray et al., 2006).

It has also been noted earlier that the proportion of total $\mathrm{N}$ excreted animal ${ }^{-1}$ each day that originated from urine was not significantly affected by the grazing intensity and was proportionately 0.54 in May and 0.56 in September ( $F$ prob. $=0.538$ ). It is likely that the proportion would be higher in $\mathrm{N}$ fertilised, improved pastures (Whitehead, 1995), reflecting the $\mathrm{N}$ concentration in the diet.

\section{Conclusions}

The daily numbers of excretion events animal ${ }^{-1}$ for these cattle grazing semi-natural grasslands were similar to general values for cattle published by Whitehead (1995) of 8-12 times per day. However, as predicted from indoor feeding studies in the literature, they excreted a lower proportion of their total daily $\mathrm{N}$ excretion as urine compared with published values for cattle grazing fertilised, improved intensive swards which are also likely to graze at much higher stocking rates to match the likely higher herbage growth. The potential impact of this, along with the smaller effects of grazing intensity on stocking rates in semi-natural pastures, on losses to soil water (Smith and Monaghan, 2003) and the atmosphere (Petersen et al., 1998 ) should be examined to establish the contribution 
that grazing semi-natural grasslands can make to resource protection.

\section{Acknowledgements}

This work was funded by the UK Department for Environment, Food and Rural Affairs of England and Wales and was carried out in accordance with the welfare standards approved by Rothamsted Research's Ethical Review Procedure. Rothamsted Research, North Wyke is supported by the UK Biotechnology and Biological Sciences Research Council.

\section{References}

Aland, A., Lidfors, L., Ekesbo, I., 2002. Diurnal distribution of dairy cow defecation and urination. Appl. Anim. Behav. Sci. 78, 43-54.

Betteridge, K., Andrewes, W.G.K., 1986. A device for measuring and sampling urine output from free-grazing steers. J. Agric. Sci. Camb. 106, 389-392.

Betteridge, K., Andrewes, W.G.K., Sedcole, J.R., 1986. Intake and excretion of nitrogen, potassium and phosphorus by grazing steers. J. Agric. Sci. Camb. 106, 393-404.

Bilotta, G.S., Brazier, R.E., Haygarth, P.M., 2007. The impacts of grazing animals on the quality of soils, vegetation, and surface waters in intensively managed grasslands. Adv. Agron. 94, 237-280.

Cox, D.R., Lewis, P.A.W., 1966. The Statistical Analysis of Series of Events. Methuen, London.

Dove, H., Mayes, R.W., 1991. The use of plant wax alkanes as marker substances in studies of the nutrition of herbivores: a review. Aust. J. Agric. Res. 42, 913-952.

Dumont, B., Rook, A.J., Coran, C., Röver, K.-U., 2007. Effects of livestock breed and grazing intensity on biodiversity and production in grazing systems. 2. Diet selection. Grass Forage Sci. 62, 159-171.

Hack-ten Broeke, M.J.D., Van der Putten, A.H.J., 1997. Nitrate leaching affected by management options with respect to urine-affected areas and groundwater levels for grazed grassland. Agric. Ecosyst. Environ. $66,197-210$.

Hutchings, N.J., Olesen, J.E., Petersen, B.M., Berntsen, J., 2007. Modelling spatial heterogeneity in grazed grassland and its effects on nitrogen cycling and greenhouse gas emissions. Agric. Ecosyst. Environ. 121, 153-163.

Isselstein, J., Griffith, B.A., Pradel, P., Venerus, S., 2007. Effect of livestock breed and grazing intensity on biodiversity and production in grazing systems. 1. Nutritive value of herbage and livestock performance. Grass Forage Sci. 62, 145-158.

Jeffery, M.R., 2004. A simple method for collecting urine samples from male cattle. Aus. J. Exp. Agric. 44, 11-12.

Jones, D.I.H., Haywood, M.V., 1975. The effect of pepsin treatment of herbage on the prediction of dry matter digestibility from solubility in fungal cellulase solutions. J. Sci. Food Agric. 26, 711-718.

Kartchner, R.J., Rittenhouse, L.R., 1979. A feces-urine separator for making total fecal collections from the female bovine. J. Range Manage. 32, 404-405.

Karn, J.F., 2001. Phosphorus nutrition of grazing cattle: a review. Anim. Feed Sci. Technol. 89, 133-153.
Lamoot, I., Callebaut, J., Degezelle, T., Demeulenaere, E., Laquiere, J., Vandenberghe, C., Hoffmann, M., 2004. Eliminative behaviour of freeranging horses: do they show latrine behaviour or do they defecate where they graze? Appl. Anim. Behav. Sci. 86, 105-121.

Lesperance, A.L., Bohman, V.R., 1961. Apparatus for collecting excreta from grazing cattle. J. Anim. Sci. 20, 503-505.

Morton, J.D., Baird, D.B., 1990. Spatial distribution of dung patches under sheep grazing. NZ. J. Agric. Res. 33, 285-294.

Murray, P.J., Cook, R., Currie, A.F., Dawson, L.A., Gange, A.C., Grayston, S.J., Treonis, A.M., 2006. Interactions between fertilizer addition, plants and the soil environment: implications for soil faunal structure and diversity. Appl. Soil Ecol. 33, 199-207.

Orr, R.J., Griffith, B.A., Cook, J.E., Champion, R.A., 2012. Ingestion and excretion of nitrogen and phosphorus by beef cattle under contrasting grazing intensities. Grass Forage Sci. 67, 111-118.

Orr, R.J., Penning, P.D., Parsons, A.J., Champion, R.A., 1995. Herbage intake and $\mathrm{N}$ excretion by sheep grazing monocultures or a mixture of grass and white clover. Grass Forage Sci. 50, 31-40.

Orr, R.J., Rutter, S.M., Penning, P.D., Rook, A.J., 2001. Matching grass supply to grazing patterns for dairy cows. Grass Forage Sci. 56, 352-361.

Parsons, A.J., Orr, R.J., Penning, P.D., Lockyer, D.R., 1991. Uptake, cycling and fate of nitrogen in grass-clover swards continuously grazed by sheep. J. Agric. Sci. Camb. 116, 47-61.

Petersen, S.O., Sommer, S.G., Aaes, O., Soegaard, K., 1998. Ammonia losses from urine and dung of grazing cattle: effect of $\mathrm{N}$ intake. Atmos. Environ. 32, 295-300.

Rodwell, J.S., 1992. Grasslands and Montane Communities. British Plant Communities, vol. 3. Cambridge University Press, ISBN 0521391660.

Rook, A.J., Dumont, B., Isselstein, J., Osoro, K., Wallis de Vries, M.F., Parente, G., Mills, J., 2004. Matching type of livestock to desired biodiversity outcomes in pastures - a review. Biol. Conserv. 119, 137-150.

Rook, A.J., Penning, P.D., 1991. Synchronisation of eating, ruminating and idling activity by grazing sheep. Appl. Anim. Behav. Sci. 32, 157-166.

Rutter, S.M., Griffith, B.A., Cook, J.E., Champion, R.A., 2006. Using GPS animal tracking and vegetation mapping to estimate diet selection in cattle grazing semi-natural pastures. In: Proc. Int. Cong. Int. Soc. Appl. Ethol., Bristol, 8-12 August.

Semmartin, M., Oesterheld, M., 2001. Effects of grazing pattern and nitrogen availability on primary productivity. Oecologia $126,225-230$.

Scimone, M., Rook, A.J., Garel, J.P., Sahin, N., 2007. Effects of livestock breed and grazing intensity on grazing systems: 3. Effects on diversity of vegetation. Grass Forage Sci. 62, 172-184.

Smith, C., Monaghan, R.M., 2003. Nitrogen and phosphorus losses in overland flow from a cattlegrazed pasture in Southland. NZ. J. Agric. Res. $46,225-237$.

Stillwell, M.A., Senft, R., Rittenhouse, L.R., 1983. Total urine collection from free-grazing heifers. J. Range Manage. 36, 798-799.

Taylor, J.A., Robinson, G.G., Hedges, D.A., Whalley, R.D.B., 1987. Camping and faeces distribution by Merino sheep. Appl. Anim. Behav. Sci. 17, 273-288.

Thomas, T.A., 1977. An automated procedure for the determination of soluble carbohydrates in herbage. J. Sci. Food Agric. 28, 639-642.

Tyson, K.C., Garwood, E.A., Armstrong, A.C., Scholefield, D., 1992. Effects of field drainage on the growth of herbage and the liveweight gain of grazing beef cattle. Grass Forage Sci. 47, 290-301.

Whitehead, D.C., 1995. Grassland Nitrogen. CABI Publishing, Wallingford, UK, ISBN 0851989152.

Yamulki, S., Jarvis, S.C., Owen, P., 1998. Nitrous oxide emissions from excreta applied in a simulated grazing pattern. Soil Biol. Biochem. 30 491-500. 